patient and physician global disease activity assessment (GDA) in a Likert scale (0-4), ESR and CRP. Those patients that fulfilled 5 or more of the next criteria were considered to have an active disease: pain score $>25 \mathrm{~mm}$; TJC $>5$; SJC $>3$; patient GDA $>1$; physician GDA > 1; ESR > $25 \mathrm{~mm}$ and RCP $>0.8 \mathrm{mg} / \mathrm{dl}$. DAS28 score was also calculated. Student t test and Pearson correlation test were applied for statistical analysis.

Results IL-15 and TNF-a serum levels from RA patients were significantly higher than that from healthy donors $(314.6 \pm 72.3$ vs. $12.9 \pm 3.1 \mathrm{pg} / \mathrm{ml}, \mathrm{p}=0.0001$; and $233.1 \pm 97.9$ vs $74.2 \pm$ $30 \mathrm{pg} / \mathrm{ml}, \mathrm{p}=0.06$, respectively). The percentage of CD69 positive PBL in RA patients was also higher that in controls $(12.6 \pm$ 1.2 vs. $9.7 \pm 0.8 ; \mathrm{p}=0.03)$. The percentage of $\mathrm{CD} 69^{+} \mathrm{PBL}$ correlated with DAS score $(\mathrm{r}=0.382 ; \mathrm{p}<0.05)$. In addition, MS and TNF-a levels also correlated $(\mathrm{r}=0.49 ; \mathrm{p}=0.015)$. Mean serum concentrations of IL15 and TNF-a in patients with active disease were higher than these cytokine levels in patients considered inactive ( 274 vs. $112.4 \mathrm{pg} / \mathrm{ml}$ and 337.6 vs. $211 \mathrm{pg} /$ $\mathrm{ml}$, respectively), although this difference did not reached statistical significance likely due to the low number of patients with inactive disease $(n=6)$.

Conclusion Our data showed a correlation between CD69 expression on PBL and clinical parameters, suggesting a pathogenic role for this molecule in RA. Further studies are needed to evaluate the clinical significance of elevated levels of IL15 in RA patients.

\section{THU0087 INCREASED GLUCOCORTICOID BETA MRNA IN PERIPHERAL BLOOD MONONUCLEAR CELLS OF RHEUMATOID ARTHRITIS PATIENTS}

${ }^{1} \mathrm{~A}$ Goecke, ${ }^{2} \mathrm{M}$ Alamo, ${ }^{2} \mathrm{M}$ Cuchacovich, ${ }^{1} \mathrm{C}$ Sepulveda, ${ }^{2} \mathrm{H}$ Gatica. ${ }^{1}$ Physyology Program ICBM Faculty of Medicine; ${ }^{2}$ Rheumatology Sevice, Hospital Clinico University of Chile, Santiago, Chile

\subsection{6/annrheumdis-2001.964}

Background Rheumatoid Arthritis is an autoimmune inflammatory disease. A glucocorticoid resistance has been postulated as a factor involved in the pathogenesis of this disease. ${ }^{1}$ The mechanisms involved in this GC-resistance has not been elucidated. Glucocorticoids' effects are mediated trough an intracelular receptor, the glucocorticoid receptor (GCR). Thereare two isoforms of the GCR termed alpha and beta. The Beta isoform has recently been demostrated to act as a dominant negative inhibitor of the classic glucocorticoid receptor alpha. ${ }^{2}$ As a potential in vivo inhibitor of GCR alpha activity, the expression of GCR beta isoform may be an important factor regulating target cell responsiveness to glucocorticoids.

Objectives This study evaluated if there is an increase in GCR beta mRNA in peripheral blood mononuclear cells (PBMNC) from active newly diagnosed rheumatoid arthritis (RA) patients as compared to PBMNC from normal controls.

Methods PBMNC were obtained from 9 active RA patients and 9 normal controls, matched by age and sex. A patient was defined as having an active disease if 3 of the following criteria were fulfilled: Erytrosedimentation rate $>30 \mathrm{~mm} /$ hour, morning stiffness $>1 \mathrm{~h},>6$ tender joints, $>3$ swollen joints. The GCR alpha and beta were evaluated by semiquantitative RT-PCR. The RT-PCR products for both isoforms of glucocorticoid receptor were electrophoretically fractioned on $2 \%$ agarose gels stained with ethidium bromide. The intensity of ethdium bromude fluorescence was measured densitometrically and expressed as optical density units (ODU). The presence of statistically significant differences in ODU between groups was evaluated by the Wilcoxon test for matched pairs.

Results RA patients presented a significant increase in the expression of GCR beta mRNA (median 571, range 208-968 ODU vs median 317, range 83-563 ODU in controls; $\mathrm{P}=0.007$ ) with no change in GCR alpha mRNA compared to controls.

Conclusion RA patients present an increased expresion of the inhibitory beta isoform of the GCR in PBMNC. Glucocorticoids have well known anti-inflammatory properties, therefore an increased proportion of the inhibitory isoform of the glucocorticoid receptor could lead to a glucocorticoid-resistance status, wich could be a pathogenetic factor in RA by favouring the persistence of inflammatory processes.

\section{REFERENCES}

1 Morand EF, Jefferiss M, Dixey J, Mitra D, Goulding NJ. Impaired glucocorticoid induction of mononuclear leucocyte lipocortin-1 in rheumatoid arthitis. Arthritis Rheum. 1994:37:207-11

2 Bamberger CM, Bamberger AM, de Castro M, Chrousos GP. Glucocorticoid receptor beta a potential endogenous inhibitor of glucocorticoid actions in humans. J Clin Invest. 1995;95:2435-41

\section{THU0088 PREVENTION OF A NOVEL AND NEWLY DISCOVERED ANTI-ARTHRITIC COMPOUND SX-5452 ON DEVELOPMENT OF COLLAGEN-INDUCED ARTHRITIS IN DBA/1 MICE AND AUTOIMMUNE RESPONSES IN MRL/ LPR MICE}

${ }^{1} \mathrm{MN}$ Itoh, ${ }^{1} \mathrm{M}$ Tanaka, ${ }^{1} \mathrm{~S}$ Mishina, ${ }^{2} \mathrm{~T}$ Murata, ${ }^{3} \mathrm{~K}$ Ohno. ${ }^{1}$ Pharmacology I//Discovery Research Laboratories; ${ }^{2} R \& D$ Planning; ${ }^{3}$ Chemistry I, Dainippon Pharmaceutical Co., Ltd., Suita, Japan

\subsection{6/annrheumdis-2001.965}

Background In trying to elucidate the value of new drug regimens in rheumatoid arthritis (RA), it is of critical importance to use animal models which share as many features as possible with the human disease. Collagen 0 induced arthritis) CIA) is characterised by development of both cellular and humoral immune responses directed against heterologous and autologous CII. Newly discovered diphenylpyrimidine amino acetamide derivatives pretreatment has been shown in vitro to reduce anti-CII antibody formation. Against this background, we wanted to investigate the clinical effects of SX-5452 on CIA and MRL/lpr. Objectives To investigate the effectiveness of SX-5452 in preventing the development of arthritis/autoimmune diseases and to compare the potency/mechanisms with Leflunomide, a novel anti-rheumatic drug.

Methods Male DBA/1 mice and female MRL/lpr/lpr mice were used. The degrees of swelling, redness were evaluated macroscopically and intensity of inflammation was evaluated by histologically. At the same time the antibody formation was evaluated in vivo and in vitro.

Results Oral administration of SX-5452(0.03 mg/kg/day-10 mg/ $\mathrm{kg} /$ day) from the day of immunisation with CII strongly and dose-dependently suppressed the development of arthritis. SX5452 at the dose of $10 \mathrm{mg} / \mathrm{kg}$ prevented completely the development of arthritis in both arthritic score and histological changes. Furthermore administration of SX-5452 at the dose of $10 \mathrm{mg} / \mathrm{kg}$ one a week also suppressed almost completely the development of CIA. It also showed inhibitory effect on the production of anti-CII antibody in CIA mice as well as anti-DNA antibody in MRL/lpr mice. These effects were at least three-fold more potent than those of leflunomide. MAPK-pathway and tyrosine phosphorylation are raised as the possible molecular mechanisms. 